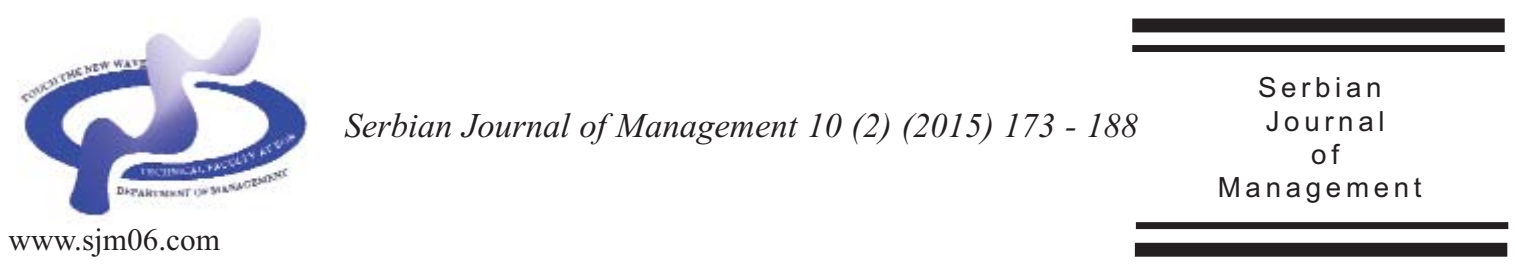

\title{
EXPLORING THE CUSTOMER PERCEIVED VALUES AS ANTECEDENT OF PURCHASE BEHAVIOR
}

\author{
Nabi Allah Dehghan ${ }^{a}$, Hamid Alizadeh ${ }^{b *}$ and Sedighe Mirzaei-Alamoutic

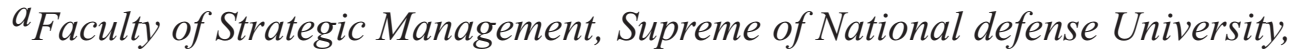 \\ Babaee Highway, 1698613411 ,Tehran, Iran

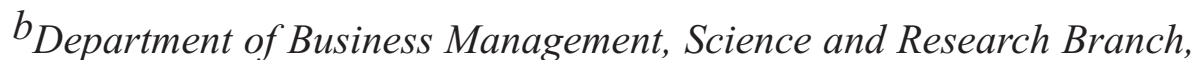 \\ Islamic Azad University, North Satari Highway, 1477893855, Tehran, Iran \\ ${ }^{c}$ Department of Business Management, Science and Research Branch, \\ Islamic Azad University, University Avenue , 34185-1416, Qazvin, Iran
}

(Received 1 March 2015; accepted 5 May 2015)

\begin{abstract}
Today, more than ever we see an increase in the importance of customer-orientation, and it's consideration as an important competitive advantage of organizations and its role in business success and development. The aim of this study is to survey a development of customer-oriented culture in chain stores, and also to discuss the relationships between the dimensions of customer value, perceived value, customer satisfaction, brand loyalty and repurchase intention. This study is based on a survey research, and the statistical population is consisted of customers a famous chain store in Tehran, and the selected samples are 390 persons from those customers. The data collection tool was a questionnaire and Confirmatory factor analysis and structural equation modeling techniques have been used to analyze the collected data. The results show that in consider chain stores, customer value affects on the Customer satisfaction. Moreover, it shows that customer satisfaction also affects brand loyalty. And at last it reveals that the proposed model explains the relationships between aspects of customer value, perceived value, customer satisfaction, brand loyalty and repurchase intention in an effective way.
\end{abstract}

Keywords: customer value, perceived value, customer satisfaction, brand loyalty, repurchase intention, chain stores

\section{INTRODUCTION}

In recent years, chain stores have grown rapidly and now it has been several years since they are included among the main priorities of the Ministry of Commerce on the reform of the distribution system. Due to the existence of many problems in the field of goods distribution, most affected by two factors which were poor economic

\footnotetext{
* Corresponding author: hamid.alizadeh@srbiau.ac.ir

DOI:10.5937/sjm10-7844
} 
conditions and the traditional distribution system, the government decided to launch a set of modern chain stores to improve the status of distribution and to prevent turbulence in the market.

In Iran, in the field of academic, activities conducted on the topic of customer loyalty and its role in repurchasing has been limited in number; whereas addressing issues regarding customer-orientation and customer loyalty and providing appropriate models and structures for it in service businesses including chain stores is considered a necessity. Also, with transition from traditional economy and with increasing intensification of competition in new scales, the customer has been turn to be a basic element in all activities of organizations; so that from a competitive standpoint, the survival of organizations depends on identifying and attracting new customers and retain existing customers. Yet, advances in communications, the Age of Information and the emergence of new communication tools, have faced the organizations with lots of different customers and have introduced many options to them, thus the results is the more choices for customers and markets instability. In the meantime, scholars of management and marketing recommend customer care and proper ways of understanding its values, which among its benefits, the increase in income growth (for increasing customers satisfaction), reduction in selling and distribution costs, and minimizing the costs of supporting, can be mentioned (Elahi \& Heydari, 2006). Consumers are not just looking to buy a product; they also want their values to be considered. Therefore, a buyer of a perfume is not just looking to buy a product, but he also seeks the sensual and romantic pleasures along with having a series of psychological, emotional and social benefits which occur after his purchase. Thus, managers must be able to explore certain motives and values of consumers which are satisfied with the product or brand names, and according to them they should create marketing mixes. One of the major concerns for every store is to use marketing tactics to increase customer's satisfaction and to force them to buy again.

\section{LITERATURE REVIEW AND CONCEPTUAL MODEL}

In today's highly competitive environment, most companies are focused on customer retention as a key to success. Marketing activities are established mainly based on customer value.

Although the importance of customer expected value is fully known, the relevant researches are quite sparse and there is no clear definition of the concept of customer value. Primal studies on the effect of profits of Market Strategies (PIMS) states that the definition of the value is based on product quality, relative price and customer expectations (Wang et al., 2004).

The value is considered as customer overall assessment of the utility of a product based on what is received and what is given (Zeithaml, 1998). Buyers' understanding of the value, results from the interaction between the quality, or the benefits gained from buying a product on the one hand, and a sense of loss on the side of customer during the payment of the price, on the other hand (Dodds et al., 1991). Butz and Goodstein (1996) see it as a friendly agreement between the customer and the manufacturer, after receiving the product from the supplier. Although the importance of customer 
perceived value has been considered, scholars have focused their attention on the operationalization of this concept. Traditionally, customer value can be understood in terms of an interaction between quality and price. Today, of course, companies search for other ways to create and deliver superior value to the customer. As Sweeney and Soutar (2001) have shown in their researches, it is necessary for companies to research about the other factors that create gained and lost benefits and they should also review the managerial applications of these factors. For example Kotler (1997) believes that customer value could be expressed in terms of product value, service value, the value of labor and mental image. Although it is clear that Kotler's approach widely comes from the company and not the customer's perspective, at least it is not fully based on the customer. However, in this study, sacrifices are considered something more than price. The term 'sacrifice' refers to what customer loses in order to obtain or consume a product (good or service). These sacrifices also include of non-financial factors such as time, effort and energy which may even play more important roles than price. For example, many customers value their time more than the price and they even consider it as their most fundamental asset.

One of the key concepts in the strategies and existing distinctions between retails is customer value; because it makes them understand what customers want and what they believe in getting things and using them. Creating and delivering value to customers, is a background for retail stores in order to survive in today's competitive marketing (Rintamaki et al., 2006).

This study suggests the aspects of customer value in terms of four key aspects: perceived sacrifices, functional value, emotional value and social value; each of these aspects may play a different role in the process of understanding the customer and therefore have different roles in customers repurchasing. Emotional value refers to the desirability of effective modes which are arisen by the product or service. Social value refers to the social desirability of the product or service. Functional value refers to the desirability resulting from the quality perceived by the customer and his expected performance of the product or services, and perceived sacrifices means that injuries and fatalities resulting from the purchase of goods or services which is combined with the increased cost of short-and long-term purchase.

\subsection{Customer Value and Customer Satisfaction, Brand Loyalty, Repurchase} Intention

Although there is remarkable information about the concept of customer value and its relationship to quality of services and customer satisfaction, there are relatively few empirical researches on the issue. Only a few studies have been done concerning the formation of superior customer value in customer perspective, and also there are no studies regarding the way we can develop a more reliable and valid measure for such an important and complex structure (Sweeny \& Soutar, 2001).

A review of previous theoretical history shows satisfaction and loyalty concepts are two strong predictor factors of customer retention or in other words, they are the factors of keeping trade between customer and producer of services or repurchase of a special brand (Olsen \& Johnson, 2003).

Loyalty to the brand, as an important 
result of trusting, is considered as a behavioral notion about the brand or an actual pattern of shopping behavior, or both (Matzler et al., 2008). Repurchase intention, is the iterative process of purchasing goods and certain services from one particular store (Hellier et al., 2003) and the main reasons are the post-shopping experiences. Instead of attracting new customers, companies can retain previous customers with less evaluation costs. This study seeks to answer the following question: How is the impact of customer value and perceived value, on customer satisfaction, brand loyalty and repurchase intention?

In their studies, have found the direct and indirect impact of customer value on the intention to repurchase (Wang et al., 2004). Although many theoretical studies which have mentioned the superior value to customers, have proved its deep influence on customers purchase or their repurchase intention and also their decision to retain their close relationship with the company, but there is little knowledge about the effects of customer value on customer behavior. Also, customer value paves the way for satisfaction which has an impact on loyalty, which includes recommendation to others and repurchase intention (Lam et al., 2004). Customer's perception of value reflects the positive impact of products or services evaluation and buying behavior, and results in repurchasing which ultimately has an impact on his decision (Cronin et al., 2000). Perceived quality creates perceived value, which eventually leads to intention of purchasing. Also Oh (1999), argues that customer value has a direct impact on customer's purchase intention. The value, leads to loyalty and satisfaction, and also involvement of product as a moderating variable affects on this relationship (Chen \&
Tsai, 2008).

H1: Functional value has a direct relationship with customer satisfaction.

H2: Social value has a direct relationship with customer satisfaction.

H3: Emotional value has a direct relationship with customer satisfaction.

H4: Perceived sacrifice has a direct relationship with customer satisfaction.

H5: Functional value has a direct relationship with repurchase intention.

H6: Social value has a direct relationship with repurchase intention.

H7: Emotional value has a direct relationship with repurchase intention.

H8: Perceived sacrifice has a direct relationship with repurchase intention.

H9: Functional value has a direct relationship with brand loyalty.

H10: Social value has a direct relationship with brand loyalty.

H11: Emotional value has a direct relationship with brand loyalty.

H12: Perceived sacrifice has a direct relationship with brand loyalty.

\subsection{Perceived value and customer} satisfaction, brand loyalty, repurchase intention

Perceived value in consumer behavior theory includes the utilitarian and hedonistic values; the utilitarian value is the ability to perform everyday tasks in life by the consumer; in contrast, the hedonistic value is the potential factor to enjoy a product category. These values appear to be two contradictory paradigms, both directly affects on consumer behavioral intentions (Chadhuri \& Holbrook, 2001). The more important issue is how the perceived value relates to the consumer's after-purchase 
reactions, including customer satisfaction and desires (Ha \& Jang, 2010).

Perceived value in marketing has been defined in terms of customer's assessment of costs and obtained benefits of purchasing a product or service (Yang \& Peterson, 2004). The results of studies on the relationship between perceived value and customer satisfaction in traditional retails, also shows that in many cases the perceived value strongly influences customer satisfaction (Eggert \& Ulaga, 2002). Verbal communication, loyalty and participation in the act of re-supporting, has a positive influence on the value of hedonistic purchasing, but it does not seem to affect the tendency to re-support. The value of hedonistic purchasing compared to the value of utilitarian purchasing has a stronger impact on verbal communication, but both values (hedonistic, utilitarian) insist on loyalty. Finally, the utilitarian value has a stronger influence on tendency to re-support, in compare to the hedonistic value. They also found that the value of hedonistic purchasing, in a positive and effective manner, affects the tendency to loyalty and re-support, while it has a negative impact on participation in re-support. But ultimately, the utilitarian value compared to hedonistic value, has a stronger influence on tendency to re-support (Jones et al., 2006).

Perceived quality creates perceived value that ultimately leads to purchase intention. Perceived value increases brand loyalty, customer satisfaction and chance of future purchases (Jenkins, 2010).

Also in the field of marketing, the concept of perceived value as one of the most important criteria of gaining competitive advantage has been considered, and even it has been mentioned as the most important indicator of repurchase intention (Petrick,
2002). In conducted researches regarding the creation of value for customers, there is a strong and direct relationship between the profitability and organization's growth, customer loyalty, customer satisfaction, value of goods and services provided to the customer, quality and efficiency of services and also capabilities, abilities, satisfaction and loyalty of staff (Khalifa, 2004). Research also shows utilitarian and hedonistic values affect on repurchase intention (Lai \& Chen, 2010).

H13: Utilitarian value has a direct relationship with customer satisfaction.

H14: Hedonistic value has a direct relationship with customer satisfaction.

H15: Utilitarian value has a direct relationship with brand loyalty.

H16: Hedonistic value has a direct relationship with brand loyalty.

H17: Utilitarian value has a direct relationship with repurchase intention.

H18: Hedonistic value has a direct relationship with repurchase intention.

\subsection{Customer satisfaction and brand loyalty repurchase intention}

Customer satisfaction is an overall assessment of customer experiences of companies over time and is an essential indicator of past, present and future performance of a company (Galbreath, 2010).

Customer satisfaction plays a major role in services (Edvardsson et al., 2000). Concurrent with the development of the Services, researches also have taken greater steps in defining and understanding of satisfaction in customer's perspective. In order to obtain satisfied customers, organizations must forget about exploring 
the market, advertisements, and propagations, instead they need to focus on the development of appropriate infrastructures in order to meet customer needs, by providing the best products and services (McKenna, 1991).

Through the quality and the inferred value of goods and services customer will attain true satisfaction (Riscinto-Kozub, 2008). Oliver (1997) describes satisfaction as customer's complete surrender.

Satisfaction relates to the pleasant or unpleasant feelings of the person, which arises from a comparison of his mental function with his expectations. As this definition clearly demonstrates, satisfaction depends on the mental performance and expectations. If the products performance is less than expectations, the customer will be dissatisfied. If the product appears to be in expectations level, the customer is satisfied; and if the performance of the product surpass the expectations, the customer is highly satisfied or in other words, delighted. Many companies aim to delight their customers, because the customers who are merely satisfied, when faced with a better product that is offered by other sellers, they simply change their vendor. Customers whom are very delighted and satisfied with their purchasing from a certain seller, are less willing to change their supplier, and to purchase their needed items from other sources. Great pleasure or satisfaction, not only causes the logical preference, but also creates an emotional attachment to the brand of the product. The result is the high loyalty of customer and consequently his tendency to repurchase (Kotler \& Armstrong, 2010).

H19: Customer satisfaction has a direct relationship with brand loyalty.

H20: Customer satisfaction has a direct relationship with repurchase intention.

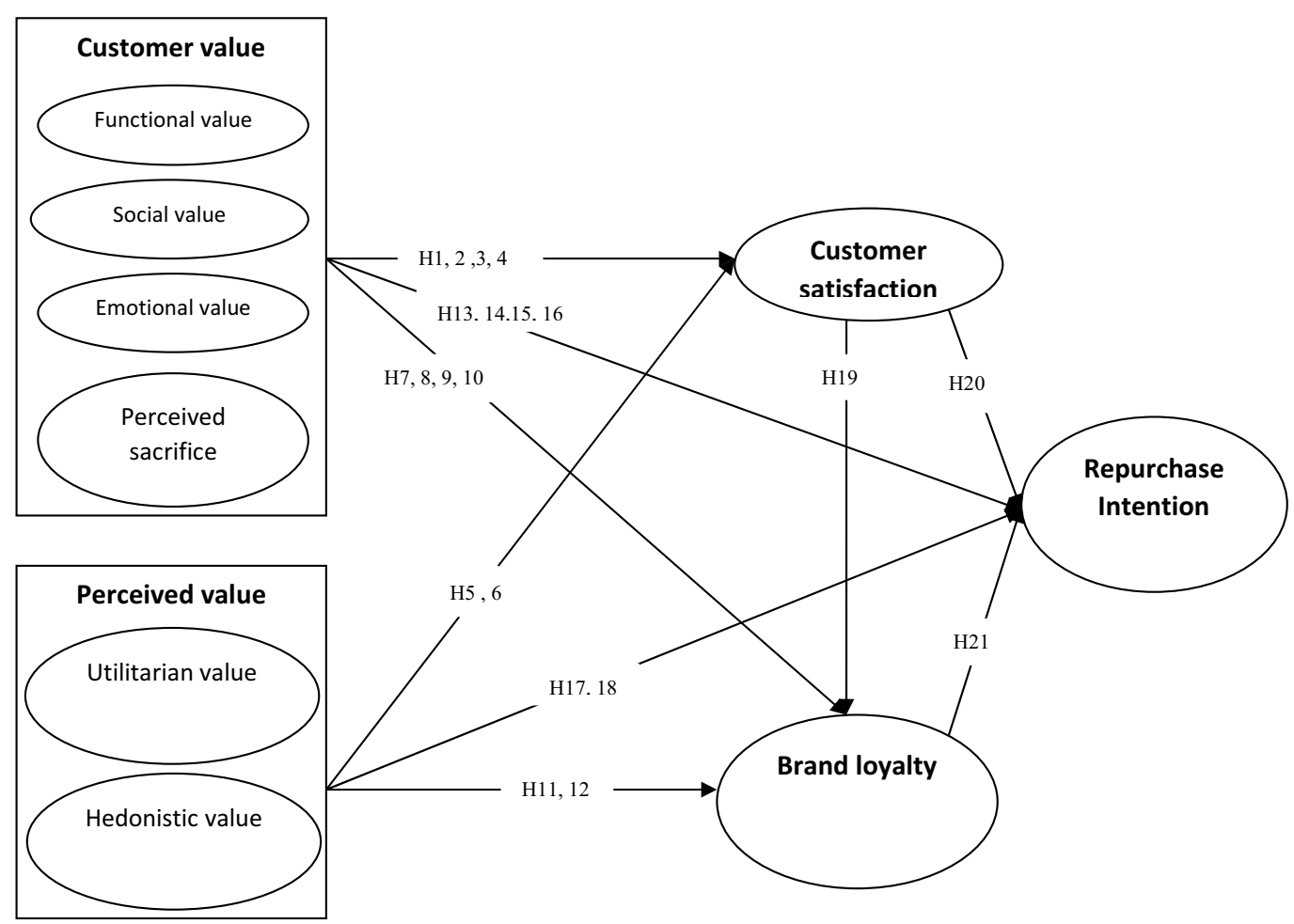

Figure 1. Proposed conceptual model 


\subsection{Brand loyalty, repurchase intention}

Customer loyalty is a reaction that customer shows to brand, service stores and product or service category (Gomez et al., 2006). The most famous and complete definition of loyalty provided by Oliver is as fallows that loyalty is a deep commitment to repurchase a product or a preferred service (Heskett et al., 1994). Loyal customers to a brand might want to pay more for a special brand because they could obtain unique values of this brand that they cannot get from any other brands. Brand loyalty also leads to great share of the market because loyal customers frequently purchase of a specific brand regardless of pressures and constraint position (Rundle-Thiele \& Mackay, 2001). A review of pervious theoretical history shows satisfaction and loyalty concepts are two strong predictor factors of customer retention or in other words they are factors of keeping trade between customer and producer of service or repurchase of a special brand (Olsen \& Johnson, 2003).

H21: Brand loyalty has a direct relationship with repurchase intention.

\section{RESEARCH METHODOLOGY}

The population of the study is people of Tehran who use consider chain stores services. The sample size was set 385 persons through Cochran formula; 400 questionnaires were distributed for further assurance and collecting the minimum required questionnaires. Table 1 show the means used to measure variables. It should be noted that the 5-point Likert Scale were used to assess the questions. Software SPSS version 18 and LISREL version 8.54 were used for data analysis.

The validity of the questionnaire was assessed by two aspects of content validity and construct validity. A total of 30 questionnaires were given to the experts and professors of marketing in order to evaluate content validity; and by using collected data all parameters had content validity. To assess construct validity, face validity, convergent and divergent methods were used. Questionnaires were handed to 45 randomly selected customers of chain stores, and they were asked to express their opinions about whether those questions were meaningful to them or not. After applying some changes and modifications, the ultimate questionnaire was finally developed and prepared. Again,

Table 1. Number of indicators and sources for construct measures

\begin{tabular}{lccc}
\hline \multicolumn{1}{c}{ Construct } & $\begin{array}{c}\text { Number } \\
\text { of indicators }\end{array}$ & Questions & Source \\
\hline Customer Value & 4 & $1-2-3-4$ & \\
Functional value & 3 & $5-6-7$ & Wang et al., 2004 \\
Social value & 4 & $8-9-10-11$ & \\
Emotional value & 6 & $12-13-14-15-16-17$ & \\
Perceived Sacrifices & & & \\
\hline Perceived Value & 2 & $18-19$ & Babin et al., 1994 \\
Utilitarian value & 3 & $20-21-22$ & \\
Hedonistic value & 3 & $23-24-25$ & Wang et al., 2004 \\
\hline Customer Satisfaction & 3 & $26-27-28$ & Wang et al., 2004 \\
\hline Brand Loyalty & 3 & $29-30-31$ & Kuo et al., 2011 \\
\hline Repurchase Intention & &
\end{tabular}


Table 2. Factor loadings, Cronbach's alpha, combined reliability, and the average variance extracted

\begin{tabular}{|c|c|c|c|c|c|}
\hline Construct & & $\begin{array}{l}\text { Factor } \\
\text { Loadings }\end{array}$ & $\begin{array}{c}\text { Cronbach's } \\
\text { Alpha }\end{array}$ & $\begin{array}{l}\text { Combined } \\
\text { Reliability }\end{array}$ & $\begin{array}{l}\text { Average } \\
\text { Variance } \\
\text { Extracted }\end{array}$ \\
\hline Functional Value & $\begin{array}{l}\text { FV1 } \\
\text { FV2 } \\
\text { FV3 } \\
\text { FV4 }\end{array}$ & $\begin{array}{l}0.72 \\
0.64 \\
0.68 \\
0.64\end{array}$ & 0.76 & 0.77 & 0.44 \\
\hline Social value & $\begin{array}{l}\text { SV1 } \\
\text { SV2 } \\
\text { SV3 }\end{array}$ & $\begin{array}{l}0.78 \\
0.55 \\
0.64\end{array}$ & 0.71 & 0.70 & 0.43 \\
\hline Emotional Value & $\begin{array}{l}\text { EV1 } \\
\text { EV2 } \\
\text { EV3 } \\
\text { EV4 }\end{array}$ & $\begin{array}{l}0.76 \\
0.64 \\
0.71 \\
0.77\end{array}$ & 0.80 & 0.81 & 0.52 \\
\hline Perceived Sacrifice & $\begin{array}{l}\text { PS1 } \\
\text { PS2 } \\
\text { PS3 } \\
\text { PS4 } \\
\text { PS5 } \\
\text { PS6 }\end{array}$ & $\begin{array}{l}0.68 \\
0.74 \\
0.81 \\
0.73 \\
0.69 \\
0.51\end{array}$ & 0.83 & 0.83 & 0.51 \\
\hline Utilitarian Value & $\begin{array}{l}\text { UV1 } \\
\text { UV2 }\end{array}$ & $\begin{array}{l}0.82 \\
0.87\end{array}$ & 0.83 & 0.83 & 0.71 \\
\hline Hedonistic Value & $\begin{array}{l}\text { HV1 } \\
\text { HV2 } \\
\text { HV3 }\end{array}$ & $\begin{array}{l}0.88 \\
0.87 \\
0.88\end{array}$ & 0.91 & 0.75 & 0.76 \\
\hline $\begin{array}{l}\text { Customer } \\
\text { Satisfaction }\end{array}$ & $\begin{array}{l}\text { CS1 } \\
\text { CS2 } \\
\text { CS3 }\end{array}$ & $\begin{array}{l}0.72 \\
0.67 \\
0.72\end{array}$ & 0.74 & 0.74 & 0.50 \\
\hline Brand Loyalty & $\begin{array}{l}\text { BL1 } \\
\text { BL2 } \\
\text { BL3 }\end{array}$ & $\begin{array}{l}0.76 \\
0.78 \\
0.72\end{array}$ & 0.79 & 0.75 & 0.56 \\
\hline $\begin{array}{l}\text { Repurchase } \\
\text { intention }\end{array}$ & $\begin{array}{l}\text { RI2 } \\
\text { RI3 }\end{array}$ & $\begin{array}{l}0.72 \\
0.87\end{array}$ & 0.81 & 0.79 & 0.63 \\
\hline
\end{tabular}

several other questionnaires were distributed among other people which its feedback indicated the face validity of the ultimate questionnaire.

Standardized factor loadings that are estimated should be higher 0.5 and ideally should be 0.7 or higher (Fornell \& Larcker, 1981). Also according to Hatcher, Factor loadings can be numerically greater than 0.6. The average variance extracted is using a single scale of convergence among a set of observed items into a structure and in fact, it is one percent of the described variance among the items. The average variance extracted should be greater than 0.5 to approve one of the scales of convergent validity. Also the combined reliability should be 0.7 or higher, which demonstrates the adequacy of internal consistency (Fornell \& Larcker, 1981). In this study, it can be seen that the CR, for all variables is greater than 0.7 , which indicates the adequacy of internal consistency and shows that the combined reliability coefficients are high. Also, according to this table it can be seen that all factor loadings are greater than 0.5 , and by taking the combined reliability coefficients into consideration, it can be said that the model has converged validity (Bagozi \& Yi, 1988), which was calculated for each construct, thus the constructs show an acceptable level of combined reliability (Table 2).

In addition, according to the average 
Table 3. Correlation between squared inter construct correlation

\begin{tabular}{lllllllll}
\hline Constructs measured & & \multicolumn{7}{c}{ SIC } \\
\hline Functional Value & 0.0961 & 0.0784 & 0.0361 & 0.0729 & 0.0484 & 0.25 & 0.09 & 0.12 \\
Social value & 0.0961 & 0.193 & 0.04 & 0.0729 & 0.09 & 0.0729 & 0.09 & 0.22 \\
Emotional Value & 0.0784 & 0.193 & 0.044 & 0.0625 & 0.122 & 0.0784 & 0.0961 & 0.18 \\
Perceived Sacrifice & 0.0361 & 0.04 & 0.0441 & 0.0361 & 0.0484 & 0.21 & 0.784 & 0.0729 \\
Utilitarian Value & 0.0729 & 0.0625 & 0.0729 & 0.0361 & 0.108 & 0.122 & 0.0784 & 0.129 \\
Hedonistic Value & 0.122 & 0.09 & 0.0484 & 0.0484 & 0.108 & 0.122 & 0.0676 & 0.129 \\
Customer Satisfaction & 0.625 & 0.0729 & 0.0784 & 0.0441 & 0.122 & 0.09 & 0.115 & 0.144 \\
Brand Loyalty & 0.09 & 0.09 & 0.0961 & 0.0784 & 0.784 & 0.0676 & 0.115 & 0.25 \\
Repurchase intention & 0.122 & 0.22 & 0.18 & 0.0729 & 0.129 & 0.129 & 0.144 & 0.25 \\
\hline
\end{tabular}

variance extracted values and Squared inter construct correlation (Table 3 ), it can be seen that the average variance extracted of constructs was greater than the squared inter constructs correlation, and the constructs are different from each other the questionnaire has divergent validity (Paswan, 2009). To evaluate reliability, the internal consistency reliability and Cronbach's alpha coefficient were used which was greater than 0.7 for all constructs; Results show that questionnaire has reliability (Table 2).

\section{RESULTS}

Recognition of the demographic characteristics of the sample is useful because it helps to define general characteristics and features of the studied population for other researchers. In addition, this recognition makes information obtained from this study useful to generalize the results to other population or design questions for future research. Demographic characteristics used in this study includes items such as age, marital status, gender, education, occupation, monthly costs and post-shopping experience in the store (Table 4).

In assessing each of these models and before approving the structural relations, the suitability and desirability of the measurement model must be ensured. In general, there are several characteristics of fitness for evaluating the confirmatory factor analysis model. In this study, the degree of

\section{Table 4. Demographic characteristics}

\begin{tabular}{|c|c|c|}
\hline Demographic variables & ẩumber & Percent \\
\hline $\begin{array}{l}\text { Gender } \\
\text { Men } \\
\text { women } \\
\text { Total sum }\end{array}$ & $\begin{array}{l}189 \\
201 \\
390\end{array}$ & $\begin{array}{l}51.50 \\
48.50 \\
100\end{array}$ \\
\hline $\begin{array}{l}\text { Age } \\
\text { Under } 25 \text { years } \\
\text { Between } 26 \text { to } 30 \text { years } \\
\text { Between } 31 \text { to } 35 \text { years } \\
\text { Between } 36 \text { to } 40 \text { years } \\
\text { Above } 41 \text { years } \\
\text { Total Sum }\end{array}$ & $\begin{array}{c}59 \\
104 \\
63 \\
27 \\
137 \\
390\end{array}$ & $\begin{array}{l}15.1 \\
26.7 \\
16.2 \\
6.9 \\
35.1 \\
100\end{array}$ \\
\hline $\begin{array}{l}\text { Marital Status } \\
\text { Single } \\
\text { Married } \\
\text { Total Sum }\end{array}$ & $\begin{array}{l}139 \\
251 \\
390\end{array}$ & $\begin{array}{l}35.6 \\
64.4 \\
100\end{array}$ \\
\hline $\begin{array}{l}\text { Education } \\
\text { Diploma \& under diploma } \\
\text { Upper Diploma } \\
\text { Bachelors } \\
\text { MA \&PhD } \\
\text { Total Sum }\end{array}$ & $\begin{array}{c}116 \\
52 \\
158 \\
64 \\
390\end{array}$ & $\begin{array}{l}29.7 \\
13.3 \\
40.5 \\
16.4 \\
100\end{array}$ \\
\hline $\begin{array}{l}\text { Job } \\
\text { Employee } \\
\text { Self-employed } \\
\text { Housekeeper } \\
\text { Student } \\
\text { Total Sum }\end{array}$ & $\begin{array}{c}163 \\
93 \\
90 \\
44 \\
390\end{array}$ & $\begin{array}{l}41.8 \\
23.8 \\
23.1 \\
11.3 \\
100\end{array}$ \\
\hline $\begin{array}{l}\text { Household expenditure per } \\
\text { month } \\
\text { Under } 0.5 \text { Million } \\
\text { Between } 0.5 \text { to } 1 \text { million } \\
\text { Upper } 1 \text { million } \\
\text { Total Sum }\end{array}$ & $\begin{array}{c}95 \\
182 \\
113 \\
390\end{array}$ & $\begin{array}{l}24.3 \\
46.7 \\
29.0 \\
100\end{array}$ \\
\hline $\begin{array}{l}\text { Shopping Experience } \\
\text { Under } 3 \text { year } \\
\text { Between } 3 \text { to } 6 \text { year } \\
\text { Between } 6 \text { to } 9 \text { year } \\
\text { Between } 9 \text { to } 12 \text { year } \\
\text { Upper } 12 \text { year } \\
\text { Total Sum }\end{array}$ & $\begin{array}{c}50 \\
133 \\
73 \\
86 \\
48 \\
390\end{array}$ & $\begin{array}{l}12.8 \\
34.1 \\
18.7 \\
22.1 \\
12.3 \\
100\end{array}$ \\
\hline
\end{tabular}


Table 5. Fitness indexes of the measurement model of research

\begin{tabular}{lcc}
\hline Indexes & $\begin{array}{c}\text { The minimum } \\
\text { amount required }\end{array}$ & $\begin{array}{c}\text { Reported } \\
\text { amount }\end{array}$ \\
\hline Chi-square & & 664.26 \\
DF & $3>$ & 369 \\
Chi-square to DF & $0.9 \leq$ & 1.80 \\
NFI & $0.9 \leq$ & 0.90 \\
NNFI & $0.9 \leq$ & 0.93 \\
GFI & $0.9 \leq$ & 0.90 \\
IFI & $0.9 \leq$ & 0.94 \\
CFI & $0.08>$ & 0.94 \\
RMR & $0.08>$ & 0.038 \\
RMSEA & 0.045 \\
\hline
\end{tabular}

Table 6. Fitness indexes of structural model

\begin{tabular}{lcc}
\hline Index & $\begin{array}{c}\text { The minimum } \\
\text { amount required }\end{array}$ & $\begin{array}{c}\text { Reported } \\
\text { amount }\end{array}$ \\
\hline K Square & & 664.26 \\
DF & $3>$ & 369 \\
Chi-square to DF & $0.9 \leq$ & 1.80 \\
NFI & $0.9 \leq$ & 0.90 \\
NNFI & $0.9 \leq$ & 0.93 \\
GFI & $0.9 \leq$ & 0.90 \\
IFI & $0.9 \leq$ & 0.94 \\
CFI & $0.08>$ & 0.94 \\
RMSEA & & 0.038 \\
\hline
\end{tabular}

freedom chi-square indices, goodness of fit index (GFI), normed fit index (NFI), nonnormed fit index (NNFI), incremental fit index (IFI), comparative fit index (CFI) and root mean square error of approximation were used for evaluating the confirmatory factor analysis model.

The ratio of chi-square to degree of freedom should be less than 3 , and less is better because the test shows the difference between data and model.

The reported amount of GFI for this model was a remarkable 0.90 . Whatever the RMR for testing model was closer to zero, the model would have better fitness; the paltry amount of (RMR) in this study (0.038) indicates the appropriate explanation of the covariance.

Some values of CEI, GFI, NNFI, NFI indexes are greater than 0.9 and indicate a very good fitness of the designed model compared to other models.

The high amounts (0.9) of these indexes, indicate a very good fitness of the model compared to other possible models. In this study, all reported amount of indexes are above 0.9, which shows the goodness of fit of the model. Finally, the powerful index of root mean square error of approximation (RMSEA) was used to investigate how the model would combine fitness and saving. In the present study, an amount of 0.045 was reported (Table $5 \&$ Table 6 ).

A structural equation modeling (SEM) with latent variables was tested to determine the adequacy of the constructs of the model and test the hypotheses. Beginning prior research hypothesis correlation between the parameters studied is shown (Table 7).

Table 8 shows path coefficients and tvalues for the hypothesis which will be used to confirm or reject hypotheses.

Table 7. Variables correlation

\begin{tabular}{|c|c|c|c|c|c|c|c|c|c|}
\hline & 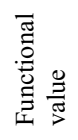 & 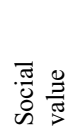 & 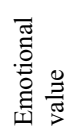 & 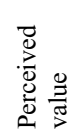 & 䏤 & 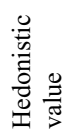 & 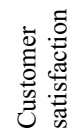 & 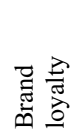 & 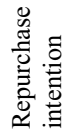 \\
\hline Functional value & 1 & & & & & & & & \\
\hline Social value & 0.31 & 1 & & & & & & & \\
\hline Emotional value & 0.28 & 0.44 & 1 & & & & & & \\
\hline Perceived sacrifice & 0.19 & 0.20 & 0.21 & 1 & & & & & \\
\hline Utilitarian value & 0.27 & 0.25 & 0.27 & 0.19 & 1 & & & & \\
\hline Hedonistic value & 0.22 & 0.30 & 0.35 & 0.22 & 0.33 & 1 & & & \\
\hline Customer satisfaction & 0.25 & 0.27 & 0.28 & 0.21 & 0.35 & 0.30 & 1 & & \\
\hline Brand loyalty & 0.30 & 0.30 & 0.31 & 0.28 & 0.28 & 0.26 & 0.34 & 1 & \\
\hline Repurchase intention & 0.35 & 0.47 & 0.43 & 0.27 & 0.36 & 0.36 & 0.38 & 0.50 & 1 \\
\hline
\end{tabular}


Table 8. Path coefficient and T amount of hypotheses

\begin{tabular}{|c|c|c|c|c|c|c|c|c|}
\hline $\begin{array}{l}\text { Hypothesis } \\
\text { Number }\end{array}$ & From Index & $\longrightarrow$ & To Index & $\begin{array}{c}\text { Path } \\
\text { Coefficients }\end{array}$ & $\mathrm{T}$ value & $\begin{array}{l}\text { Standard } \\
\text { Error }\end{array}$ & Meaningfulness & Result \\
\hline Hypothesis 1 & $\begin{array}{c}\text { Functional } \\
\text { value }\end{array}$ & - & $\begin{array}{l}\text { Customer } \\
\text { satisfaction }\end{array}$ & 0.35 & 1.75 & 0.21 & Not meaningful & $\begin{array}{c}\text { Not } \\
\text { confirmed }\end{array}$ \\
\hline Hypothesis 2 & $\begin{array}{l}\text { Social } \\
\text { value }\end{array}$ & & $\begin{array}{l}\text { Customer } \\
\text { satisfaction }\end{array}$ & -0.15 & -0.25 & 0.51 & Not meaningful & $\begin{array}{c}\text { Not } \\
\text { confirmed }\end{array}$ \\
\hline Hypothesis 3 & $\begin{array}{l}\text { Emotional } \\
\text { value }\end{array}$ & & $\begin{array}{l}\text { Customer } \\
\text { satisfaction }\end{array}$ & 0.24 & 0.44 & 0.48 & Not meaningful & $\begin{array}{c}\text { Not } \\
\text { confirmed }\end{array}$ \\
\hline Hypothesis 4 & $\begin{array}{l}\text { Perceived } \\
\text { sacrifice }\end{array}$ & & $\begin{array}{l}\text { Customer } \\
\text { satisfaction }\end{array}$ & 0.32 & 2.08 & 0.064 & Meaningful & Confirmed \\
\hline Hypothesis 5 & $\begin{array}{l}\text { Utilitarian } \\
\text { value }\end{array}$ & & $\begin{array}{l}\text { Customer } \\
\text { satisfaction }\end{array}$ & 0.38 & 4.46 & 0.065 & Meaningful & Confirmed \\
\hline Hypothesis 6 & $\begin{array}{l}\text { Hedonistic } \\
\text { value }\end{array}$ & & $\begin{array}{l}\text { Customer } \\
\text { satisfaction }\end{array}$ & 0.49 & 1.25 & 0.070 & Not meaningful & $\begin{array}{c}\text { Not } \\
\text { confirmed }\end{array}$ \\
\hline Hypothesis 7 & $\begin{array}{c}\text { Functional } \\
\text { value }\end{array}$ & & $\begin{array}{l}\text { Brand } \\
\text { loyalty }\end{array}$ & 0.46 & 1.39 & 0.43 & Not meaningful & $\begin{array}{c}\text { Not } \\
\text { confirmed }\end{array}$ \\
\hline Hypothesis 8 & $\begin{array}{l}\text { Social } \\
\text { value }\end{array}$ & & $\begin{array}{l}\text { Brand } \\
\text { loyalty }\end{array}$ & -0.81 & -0.82 & 1.05 & Not meaningful & $\begin{array}{c}\text { Not } \\
\text { confirmed }\end{array}$ \\
\hline Hypothesis 9 & $\begin{array}{l}\text { Emotional } \\
\text { value }\end{array}$ & & $\begin{array}{l}\text { Brand } \\
\text { loyalty }\end{array}$ & 0.77 & 0.83 & 0.99 & Not meaningful & $\begin{array}{c}\text { Not } \\
\text { confirmed }\end{array}$ \\
\hline Hypothesis 10 & $\begin{array}{l}\text { Perceived } \\
\text { sacrifice }\end{array}$ & & $\begin{array}{l}\text { Brand } \\
\text { loyalty }\end{array}$ & 0.13 & 1.23 & 0.12 & Not meaningful & $\begin{array}{c}\text { Not } \\
\text { confirmed }\end{array}$ \\
\hline Hypothesis 11 & $\begin{array}{l}\text { Utilitarian } \\
\text { value }\end{array}$ & & $\begin{array}{l}\text { Brand } \\
\text { loyalty }\end{array}$ & 0.21 & -2.23 & 0.14 & Meaningful & $\begin{array}{c}\text { Not } \\
\text { confirmed }\end{array}$ \\
\hline Hypothesis 12 & $\begin{array}{l}\text { Hedonistic } \\
\text { value }\end{array}$ & & $\begin{array}{l}\text { Brand } \\
\text { loyalty }\end{array}$ & -0.20 & -1.35 & 0.13 & Not meaningful & $\begin{array}{c}\text { Not } \\
\text { confirmed }\end{array}$ \\
\hline Hypothesis 13 & $\begin{array}{l}\text { Functional } \\
\text { value }\end{array}$ & & $\begin{array}{l}\text { Repurchase } \\
\text { intention }\end{array}$ & -0.47 & -0.72 & 1.17 & Not meaningful & $\begin{array}{c}\text { Not } \\
\text { confirmed }\end{array}$ \\
\hline Hypothesis 14 & $\begin{array}{l}\text { Social } \\
\text { value }\end{array}$ & & $\begin{array}{l}\text { Repurchase } \\
\text { intention }\end{array}$ & 1.53 & 0.86 & 2.62 & Not meaningful & $\begin{array}{c}\text { Not } \\
\text { confirmed }\end{array}$ \\
\hline Hypothesis 15 & $\begin{array}{l}\text { Emotional } \\
\text { value }\end{array}$ & & $\begin{array}{l}\text { Repurchase } \\
\text { intention }\end{array}$ & $-1 / 09$ & $-0 / 66$ & 2.46 & Not meaningful & $\begin{array}{c}\text { Not } \\
\text { confirmed }\end{array}$ \\
\hline Hypothesis 16 & $\begin{array}{l}\text { Perceived } \\
\text { sacrifice }\end{array}$ & & $\begin{array}{l}\text { Repurchase } \\
\text { intention }\end{array}$ & -0.03 & -0.26 & 0.18 & Not meaningful & $\begin{array}{c}\text { Not } \\
\text { confirmed }\end{array}$ \\
\hline Hypothesis 17 & $\begin{array}{l}\text { Utilitarian } \\
\text { value }\end{array}$ & & $\begin{array}{l}\text { Repurchase } \\
\text { intention }\end{array}$ & 0.23 & 0.74 & 0.40 & Not meaningful & $\begin{array}{c}\text { Not } \\
\text { confirmed }\end{array}$ \\
\hline Hypothesis 18 & $\begin{array}{l}\text { Hedonistic } \\
\text { value }\end{array}$ & & $\begin{array}{l}\text { Repurchase } \\
\text { intention }\end{array}$ & 0.18 & 0.66 & 0.34 & Not meaningful & $\begin{array}{c}\text { Not } \\
\text { confirmed }\end{array}$ \\
\hline Hypothesis 19 & $\begin{array}{c}\text { Customer } \\
\text { satisfaction }\end{array}$ & & $\begin{array}{l}\text { Brand } \\
\text { loyalty }\end{array}$ & 0.78 & 3.24 & -0.30 & Meaningful & Confirmed \\
\hline Hypothesis 20 & $\begin{array}{l}\text { Customer } \\
\text { satisfaction }\end{array}$ & & $\begin{array}{l}\text { Repurchase } \\
\text { intention }\end{array}$ & -0.11 & -0.23 & 0.82 & Not meaningful & $\begin{array}{c}\text { Not } \\
\text { confirmed }\end{array}$ \\
\hline Hypothesis 21 & $\begin{array}{l}\text { Brand } \\
\text { loyalty }\end{array}$ & & $\begin{array}{l}\text { Repurchase } \\
\text { intention }\end{array}$ & 0.74 & 1.60 & 0.65 & Not meaningful & $\begin{array}{c}\text { Not } \\
\text { confirmed }\end{array}$ \\
\hline
\end{tabular}

\section{DISCUSSION AND CONCLUSION}

Functional, social, emotional values and perceived sacrifice have significant effects on customer satisfaction (Wang et al., 2004). Perceived sacrifice is effective on customers' behavioral tendencies through influencing their satisfaction. Needs assessment study to define needs, demands, customer tests and interests, more accurately procurement to provide optimal quality of supplied products in stores, service acceleration in chain stores result in customer satisfaction and influence their behavioral tendencies (Brady et al., 2001). Functional, social and emotional values and perceived sacrifice have no significant effects on brand loyalty. Perceived sacrifice has significant relation with repurchase intention (Wang et al., 2004; Brady et al., 2001).

An important point in this study, is the lack of effect of different aspects of customer satisfaction (except for perceived sacrifice), on variables such as brand loyalty, satisfaction and repurchase intention in the statistical population. 
Customer satisfaction of purchasing of these stores and repurchasing action depends on factors such as public use of chain stores as a substitute for the purchase of retail stores for discounts, easy access to all needed commodities, establishing an accountable system to the customer, modern education system for sales forces according to recent findings of marketing, create an information system, , create internal monitoring system to monitor products to verify the health of the consuming products, producing unique products and appropriate location of the stores and they need to be considered. Customer perceived sacrifice or customer missing values has the greatest effect on satisfaction which draws emotional dimensions. Thus, it could be discussed that customer perceived sacrifice dimension has a vital and critical role in forming customer satisfaction. Utilitarian values than hedonistic values has a greater impact on customer satisfaction (Hyun et al., 2011; Ryu \& Han, 2010; Jones et al., 2006). Jones et al. (2006) study showed hedonistic purchase value has a significant effect on satisfaction. Effect of perceived values is greater than perceptual image effect on customer satisfaction and behavioral tendencies (Ryu \& Jang, 2008). Customer perceived utilitarian value correlates directly with brand loyalty, trust and customers' feelings about the brand (Chi et al., 2009). There is a significant relationship between utilitarian value and brand loyalty (Ryu \& Han, 2010). There is a significant and direct relationship between hedonistic value and brand loyalty (Chang \& Liu, 2009; Chi et al., 2009).

In general, hedonistic and utilitarian values are considered to understand customer assessment of consuming experience. There is a significant relationship between utilitarian and hedonistic values and repurchase intention (Ryu \& Han, 2010).

According to the results, it can be seen that in the population of the study, results indicate that the hedonistic value does not have a direct effect on none of the variables, including brand loyalty, customer satisfaction and repurchase intention; this means that an increase in hedonistic aspects of perceived value, such as being unique, inspirational symbolic meanings, emotional arousal, pleasurable imaginations. does not lead to an increase in customers loyalty and satisfaction of their consume experience, and therefore it does not lead to their repurchase intention, and the customers of consider chain stores pay more attention to the utilitarian aspect of perceived value.

Also, in the studied population, utilitarian value has direct effects on brand loyalty and customer satisfaction because of high cost of living. This means that an increase in utilitarian aspects of customers perceived value, such as paying attention to the economic aspects of consumption, reasonableness of deciding to purchase in terms of the used time for it, product quality and service, and balancing between customer received services and paid expenses, reasonable and fair pricing, informing and culturing of the benefits of chain stores compared with other stores to provide more perception. Make more customer loyalty to chain store and consequently their satisfaction and their tendency to return to consider store and recommend this store to others.

Shukla (2009) showed in his research that satisfaction creates brand loyalty. Consumers who have more satisfaction have more repurchase intention and tendency to recommend others. In other words, customer satisfaction growth increases the probability 
of repurchase (Lee \& Lin, 2005). Ecuadorian customers' satisfaction leads to repurchase (Brady et al., 2001). That customer satisfaction of insurance company does not lead to repurchase. Chain store managers can increase customers satisfaction and loyalty and their repurchase intention by subtracting the non-monetary costs such as increasing the amount of branches for easy access, increasing the number of employees to reduce the customer's lost time and energy, allocating parking to store and establishing banking branches around their stores (Hellier et al., 2003). Brand loyalty and purchasing cycle are to be completed by repurchasing ring and this process is the most important attitude about brand loyalty and it implies that without repurchase support, brand loyalty does not exist (Shukla, 2009). These results are consistent with his results.

It is suggested that future researches use other sampling method that is based on customer segmentation according to their values to the stores. Since cultural, geographical and economical differences have effects on the view of people, then there is a need for an exploratory study to recognize customer value and its critical dimensions of Iranian customers' aspects. Repurchase intention variable is a complex and multi-dimensional structure, so future studies could recognize other effective variables of this structure and add them to the model. Also, in order to develop current model, other variables such as confidence, commitment and replacement costs could be considered as other indexes of quality of the relation in addition to satisfaction and loyalty, because these variables have critical roles to keep stores and customers in relation with each other. Performing this study in single branch store has a significant importance because they are private and customer repurchase is very important for them. The research can dedicate a wider population to its own and implement in great industrial sale companies to produce an ultimate and useable model in all areas of sales.

\section{References}

Babin, B.J., Darden, W.R., \& Griffin, M. (1994). Work and/or fun: measuring hedonic and utilitarian shopping value. Journal of Consumer Research, 20(4), 644-656.

Bagozzi, R.P., \& Yi, Y. (1988). On the evaluation of structural equation models. Academy of Marketing Science, 23 (4), 272277.

Brady, M.K., Robertson, C.J., \& Cronin, J.J. (2001). Managing behavioral intentions in diverse cultural environments: An investigation of service quality, service value and satisfaction for American and Ecuadorian fast-food customers. Journal of International Management, 7 (2), 129-149.

Butz, H.E.J., \& Goodstein, L.D. (1996). Measuring customer value. Gaining the strategic advantage. Organizational Dynamics, 24 (3), 63-77.

Chang, H.H., \& Liu, Y.M. (2009). The impact of brand equity on brand preference and purchase intention in the service industries. Journal of the Service Industries, 29 (12), 1687-1706.

Chaudhuri, A., \& Holbrook, M.B. (2001). The Chain of Effects from Brand Trust and Brand Affect to Brand Performance. The Role of Brand Loyalty. Journal of Marketing, 65 (2), 81-93.

Chen, C.F., \& Tsai, M.H. (2008). Perceived value, satisfaction, and loyalty of TV travel product shopping: Involvement as a moderator. Tourism Management, 29, 


\title{
ИСТРАЖИВАЊЕ ОЦЕНЕ ВРЕДНОСТИ КУПЦА КАО ОСНОВЕ ПОТРОШАЧКОГ ПОНАШАЊА
}

\author{
Nabi Allah Dehghan, Hamid Alizade, Sedighe Mirzaei-Alamouti
}

\section{Извод}

У данашње време, више него икад, сведоци смо важности орјентације ка купцу и посматрања исте као важне конкурентске предности организација и њихове улоге у пословном успеху и развоју. Циљ ове студије је да се анализира развој културе оријентисане ка купцу у ланцима продавнца, као и да се дискутују односи између димензија вредности, овењене вредности, задовољства купца, лојалности бренду и поновне куповине. Ово истраживање је засновано на анкети, док су статистичку популацију чинили купци чувеног ланца продавница у Техерану. У узорку се налазило 390 испитаника. У циљу анализе сакупљених података коришћени су конфирматорна факторска анализа и техника моделовања структурних једначина. Резултати су показали да у разматраним ланцима продавница вредност производа коју процењује купац утиче на задовољство купца. Такође, показано је да задовољство купаца утиче на на лојалност бренду. На крају, показано је да предложени модел објашњава везу између аспеката вредности купца, процењене вредности, задовољства купца, лојалности бренду и намере да се исти производ купи поново, на ефикасан начин.

Кључне речи: вредност купца, процењена вредност, задовољство купаца, лојалност бренду, ланци

\section{6-1171.}

Chi, H., Yeh, H., \& Yang, Y. (2009). The Impact of Brand Awareness on Consumer Purchase Intention: The Mediating Effect of Perceived Quality and Brand Loyalty. Journal of International Management Studies, 4 (1), 135-144.

Cronin, J., Brady, M., \& Hult, G. (2000). Assessing the effects of quality, Value and customer satisfaction on consumer behavioral intentions in service environments. Journal of Retailing, 76 (2), 193-218.

Dodds, W.B., Monroe, K.B., \& Grewal, D. (1991). Effects of Price, Brand, and Store Information on Buyers' Product Evaluations. Journal of Marketing Research, 28 (3), 307319.

Edvardsson, B., Johnson, M.D., \& Strandvik, T. (2000). The effects of satisfaction and loyalty on profits and growth: Product versus services. Total Quality Management, 11 (7), 917-27.

Eggert, A., \& Ulaga, W. (2002). Customer perceived value: A substitute for satisfaction in business markets. Journal of Business and Industrial Marketing, 17 (2/3), 107-118.

Elahi, SH., \& Heydari, B. (2006). Customer Relationship Management, Tehran, Published by commercial publishing institute of Business studies and research.

Fornell, C., \& Larcker, D.F. (1981). Evaluating structural equation models with unobservable variables and measurement error.Journal of Marketing Research, 18 (1), 39-50.

Galbreath, J. (2010). The impact of strategic orientation on corporate social responsibility. International Journal of Organizational Analysis, 18 (1), 23- 40.

Gomez, B.G., Arranz, A.G., \& Cillan, J.G. (2006). The role of loyalty programs in 
behavioral and affective loyalty. Journal of Consumer Marketing, 23 (7), 387-396.

Ha, J., \& Jang, S. (2010). Perceived Values, satisfaction, and Behavioral Intentions: The Role of Familiarity in Korean Restaurants. International Journal of Hospitality Management, 29 (1), 2-13.

Hellier, P.K., Ceursen, G.M., Carr, R.A., \& Rickard, A. (2003). Customer repurchase intention: A general structural equation model. European Journal of Marketing, 37 (11/12), 1762- 1800.

Heskett, J.L., Jones, T.O., Loveman, G.W., Sasser, E.W., \& Schlesinger, L.A. (1994). Putting the Service-Profit Chain to Work. Harvard Business Review, 72 (2), 164-174.

Hyun, S.S., Kim, W., \& Lee, M.J. (2011). The impact of advertising on patrons emotional Responses, perceived value, and behavioral intentions in the chain restaurant industry: The Moderating role of advertising-induced arousal. International Journal of Hospitality Management, 30 (3), 689-700.

Jenkins, E.L. (2010). The effect of customization of customer loyalty programs on value and loyalty intention. Indiana Pursue University, Master of Science thesis.

Jones, M.A., Reynolds, K.E., \& Arnold, M.J. (2006). Hedonic and utilitarian shopping value: investigating differential effects on retail outcomes. Journal of Business Research, 59 (9), 974-981.

Khalifa, A.S. (2004). Customer value: a review of recent literature and an integrative configuration. Management Decision, 42 (5), 645-666.

Kotler, P. (1997). Marketing Management: Analysis, Planning, Implementation, and Control, 9th ed., Prentice-Hall, Upper Saddle River, ẩ J.

Kotler, P., \& Armstrong, G. (2010).
Principles of Marketing, 13th ed., Prentice Hall, Upper Saddle River, ẩ J.

Kuo, Y. F.,Wu, C.M.,\& Deng, W.J. (2009). The relationship among service quality,perceived value,customer satisfaction and post-purchase intention in mobile valueadded services. Computers in Human Behaviors, 25(4), 887- 896.

Lai, W.T., \& Chen, C.F. (2010).Behavioral intentions of public transit passenger - the role of service quality, perceived value, satisfaction and involvement. Transport Policy.

Lam, S.Y., Shankar, V., Erramilli, M.K., \& Murthy, B. (2004). Customer Value, Satisfaction, Loyalty, and Switching Costs: An Illustration from a Business-to- Business Service Context. Journal of the Academy of Marketing Science, 32 (3), 293-311.

Lee, G.G., \& Lin, H.F. (2005). Customer perceptions of e-service quality in online shopping. International Journal of Retail and Distribution Management, 33 (2/3), 161-176.

Matzler, K., Krauter, S.G., \& Bidmon, S. (2008). Risk aversion and brand loyalty: The mediating role of brand trust and brand affect. Journal of Product \& Brand Management, 17 (3), 154-162.

McKenna, R. (1991). Relationship Marketing: Successful strategies for the age of the customer, Addison-Wesley Publishing Co., Reading, MA.

Oh, H. (1999). Service quality, customer satisfaction, and customer value: A holistic perspective. International Journal of Hospitality Management, 18 (1), 67-82.

Oliver, R.L. (1997). Satisfaction: A behavioral perspective on the customer. Irwin/McGraw-Hill, ẩ ew York.

Olsen, L.L., \& Johnson, M.D. (2003). Service Quality, satisfaction and loyalty: from transaction specific to cumulative evaluations. Journal of Service Research, 5 
(3), 184-195.

Paswan, A. (2009). Confirmatory Factor Analysis and Structural Equations Modeling: An Introduction. Dept. of Marketing and Logistics, COB, University of ẩ orth Texas, USA.

Petrick, J.F. (2002). Development of a multi-dimensional scale for measuring the perceived value of a service. Journal of Leisure Research, 34 (2), 119-134.

Rintamaki, T., Kanto, A., Kuusela, H., \& Spence, M.T. (2006). Decomposing the Value of Department Store Shopping into Utilitarian, Hedonic and Social Dimensions. International Journal of Retail and Distribution Management, 34 (1), 6-24.

Riscinto-Kozub, K.A. (2008). The effects of service recovery satisfaction on customer loyalty and future behavioral intentions: An Exploratory study in the luxury hotel industry, Doctor of Philosoy Thesis, Aburun University.

Rundle-Thiele, S., \& Mackay, M. (2001). Assessing the performance of brand loyalty measures. Journal of Services Marketing, 15 (7), 529-546.

Ryu, K., \& Han, H. (2010). Influence of the Quality of food. Service and physical Environment on customer satisfaction and Behavioral Intention in Quick-casual Restaurants: moderating Role of Received price. Journal of Hospitality \& Tourism Research, 34 (3), 310-329.

Ryu, K., \& Jang, S. (2008). Influence of restaurants on emotion and behavioral intention. The Service Industrial Journal, 28 (1), 65-151.

Shukla, P. (2009). Impact of contextual factors, brand loyalty and brand switching. Journal of Consumer Marketing, 26 (5), 348-357.

Sweeney, J.C., \& Soutar, G.N. (2001). Consumer perceived value: The development of a multiple item scale. Journal of Retailing, 77 (2), 203-220.

Wang, Y., Lo, H., Chi, R., \& Yang, Y. (2004). An Integrated framework for customer value and customer-relationship management performance: a customer-based perspective from china. Managing Service Quality, 14 (2/3), 169-182.

Yang, Z., \& Peterson, R.T. (2004). Customer perceived value, satisfaction, and loyalty; The role of switching costs. Psychology and Marketing, 21 (10), 799822.

Zeithaml, V.A. (1998). Consumer perceptions of price, quality and value: A means-end model and synthesis of evidence. The Journal of Marketing, 52 (3), 2-22. 